\title{
ANALISIS KONVERGENSI EKONOMI DI PULAU JAWA MENGGUNAKAN DATA PANEL DINAMIS SPASIAL TAHUN 2013-2017
}

\section{(ANALYSIS OF ECONOMIC CONVERGENCY IN JAVA ISLAND USING SPATIAL DYNAMIC PANEL DATA 2013-2017)}

\author{
Muhammad Rizki Yudistira ${ }^{1}$, Gama Putra Danu Sohibien² \\ Politeknik Statistika STIS ${ }^{1}$ \\ Politeknik Statistika STIS ${ }^{2}$ \\ Jalan Otto Iskandardinata 64C, Bidara Cina, Jatinegara, Jakarta Timur 13330 \\ E-mail: 15.8762@stis.ac.id
}

\begin{abstract}
ABSTRAK
Pulau Jawa merupakan wilayah yang menjadi pusat pemerintahan dan perekonomian di Indonesia. Pada tahun 2011, kontribusi PDRB yang berasal dari kabupaten/kota di Pulau Jawa selalu di atas 50 persen. Akan tetapi, ketimpangan di Pulau Jawa juga besar. Berdasarkan indeks Williamson, ketimpangan yang terjadi di Pulau Jawa selalu meningkat. Oleh karena itu, dilakukan penelitian dengan mempertimbangkan hubungan antardaerah yang terdekat. Berdasarkan hasil yang didapatkan, terjadi konvergensi pada kabupaten/kota di Pulau Jawa. Ini menandakan bahwa daerah tertinggal di Pulau Jawa dapat mengejar daerah yang sudah maju. Selain itu, terdapat juga efek keterkaitan antardaerah yang mana antara satu daerah dengan daerah lainnya saling memengaruhi. Variabel PAD, IPM, persentase jalan yang berkategori baik, persentase angkatan kerja yang bekerja dan hubungan antardaerah berpengaruh positif dan signifikan terhadap PDRB per kapita di kabupaten/kota di Pulau Jawa.
\end{abstract}

Kata kunci: ketimpangan, konvergensi, panel dinamis, spasial

\section{ABSTRACT}

Java Island is an area that is the center of government and economy in Indonesia. In 2011, the GRDP contribution coming from districts / cities in Java was always above 50 percent. However, inequality in Java is also large. Based on the Williamson index, inequality that occurs in Java is always increasing. Therefore, research is conducted by considering the relationship between the closest regions. Based on the results obtained, there was a convergence in the regencies / cities in Java. This indicates that disadvantaged areas in Java can catch up with developed regions. In addition, there is also the effect of inter-regional linkages which affect one region to another. Variable PAD, HDI, percentage of roads categorized as good, percentage of labor force employed and inter-regional relations have a positive and significant effect on GRDP per capita in districts / cities in Java.

Keywords: inequality, convergence, dynamic panel, spatial

\section{PENDAHULUAN}

Pembangunan ekonomi tidak hanya memiliki tujuan utama untuk menciptakan pertumbuhan ekonomi yang tinggi, mengurangi kemiskinan, dan tingkat pengangguran, melainkan juga untuk mengurangi ketimpangan pendapatan yang terjadi antar daerah (Todaro, 2003). Salah satu indikator dalam pembangunan ekonomi dapat dilihat dari pertumbuhan ekonomi. Pertumbuhan ekonomi pada dasarnya adalah peningkatan dalam kapasitas suatu bangsa dalam waktu tertentu untuk memproduksi barang dan jasa bagi rakyatnya. Keseluruhan barang dan jasa yang dihasilkan oleh perekonomian ini dikenal sebagai Produk Domestik Bruto (PDB) pada tingkat nasional atau Produk Domestik Bruto (PDRB) pada tingkat regional (Rahayu, 2017).

Tingginya nilai PDRB belum cukup untuk menjadi tolak ukur dalam menentukan baikya pembangunan ekonomi. Wahyuni (2011) menjelaskan bahwa keberhasilan pembangunan tidak hanya diukur dari tingginya pertumbuhan ekonomi, akan tetapi juga dilihat dari tingkat kemakmuran penduduknya. Tingkat kemakmuran yang dicapai tercermin dari tingginya rata-rata pendapatan penduduk dan pemerataan hasil pembangunan. Menurut Nurhuda (2011), pertumbuhan ekonomi yang cepat namun tidak diimbangi oleh pemerataan akan menimbulkan ketimpangan wilayah. Menurut Sjafrizal (2017), faktor-faktor yang mempengaruhi ketimpangan antar wilayah antara lain 438 
perbedaan sumber daya alam, faktor demografis, alokasi dana pembangunan, konsentrasi kegiatan ekonomi wilayah, dan mobilitas barang dan jasa.

Pulau Jawa merupakan wilayah yang menjadi penyumbang PDB terbesar di Indonesia. Pada tahun 2011 hingga tahun 2017, kontribusi Pulau Jawa terhadap PDB Indonesia selalu meningkat dan berada diatas 50 persen. Pada tahun 2011, kontribusi Pulau Jawa sebesar 56,69 persen dan pada tahun 2017 kontribusi PDB Pulau Jawa naik menjadi 58,49 persen.

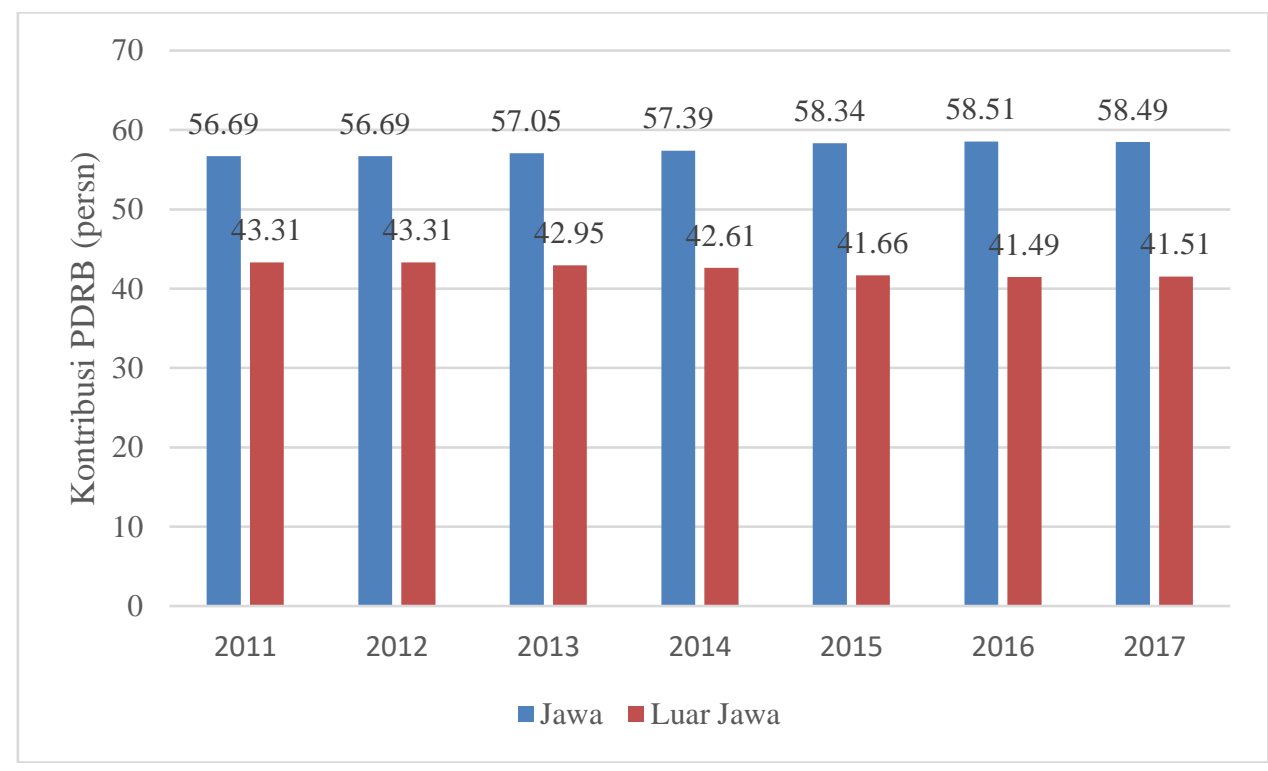

Sumber : Badan Pusat Statistik (diolah)

Gambar 1. Kontribusi PDRB Pulau Jawa dan Luar Jawa tahun 2011-2017

Selanjutnya, apabila dilihat dari rata-rata pertumbuhan ekonomi provinsi-provinsi di Pulau Jawa pada tahun 2011-2017 menunjukkan pertumbuhan yang tinggi dan selalu diatas pertumbuhan ekonomi Indonesia sejak tahun 2013. Hal ini mengindikasikan bahwa perekonomian di Pulau Jawa cenderung baik.

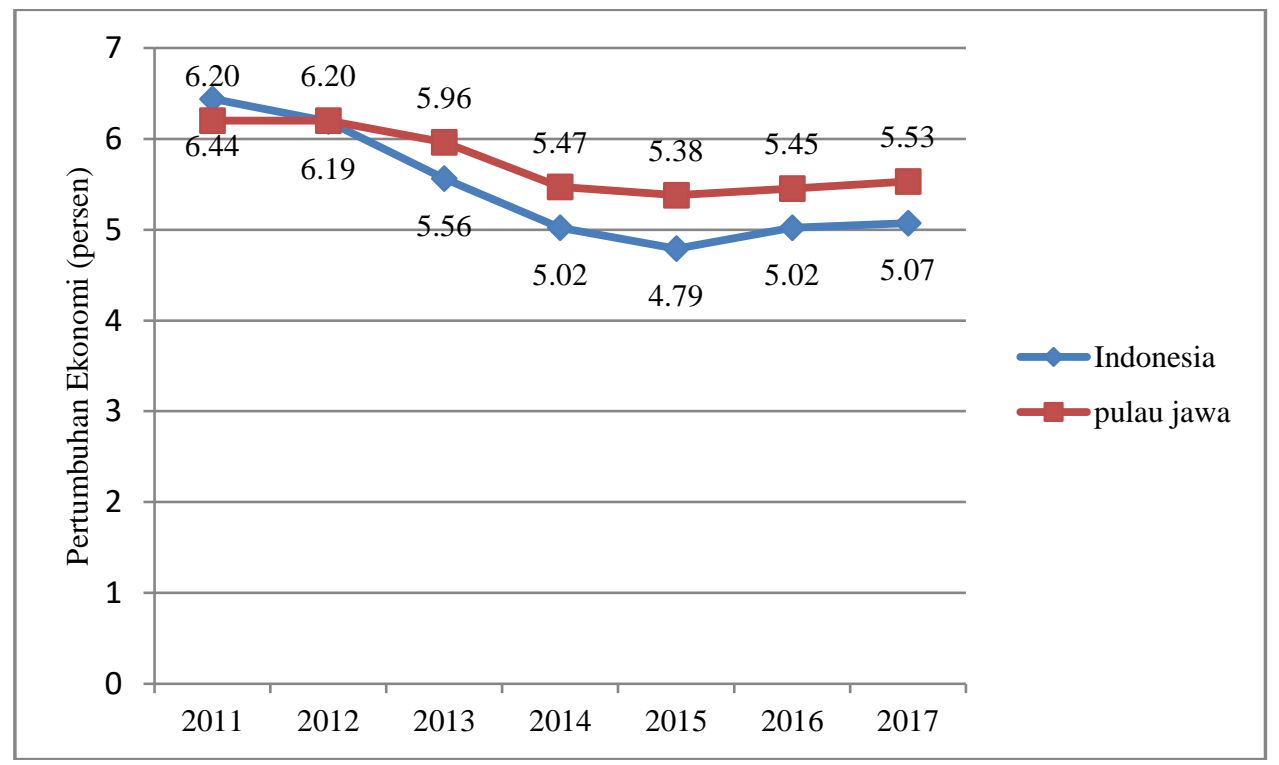

Sumber : Badan Pusat Statistik

Gambar 2. Pertumbuhan Ekonomi Indonesia dan Provinsi di Pulau Jawa Tahun 2011-2017

Namun ketimpangan di Pulau Jawa, dilihat dari indeks Williamson, pada tahun 2011 hingga 2017 selalu meningkat dan sejak tahun 2013 indeks Williamson Pulau Jawa merupakan yang tertinggi di Kawasan Barat Indonesia (KBI) dimana pada tahun 2011, nilai Indeks Williamson Pulau Jawa sebesar 1,185 dan pada tahun 2017 naik menjadi 1,190. Naiknya indeks Williamson ini menandakan kesenjangan pendapatan per kapita pada kabupaten/kota di Pulau Jawa semakin lebar dan ketimpangan ekonomi semakin besar. Ketimpangan yang semakin besar menunjukkan adanya 
indikasi pertumbuhan ekonomi pada kabupaten/kota yang relatif tertinggal semakin tertinggal dibandingkan dengan kabupaten/kota yang relatif maju dan waktu untuk mengejarnya semakin lama.

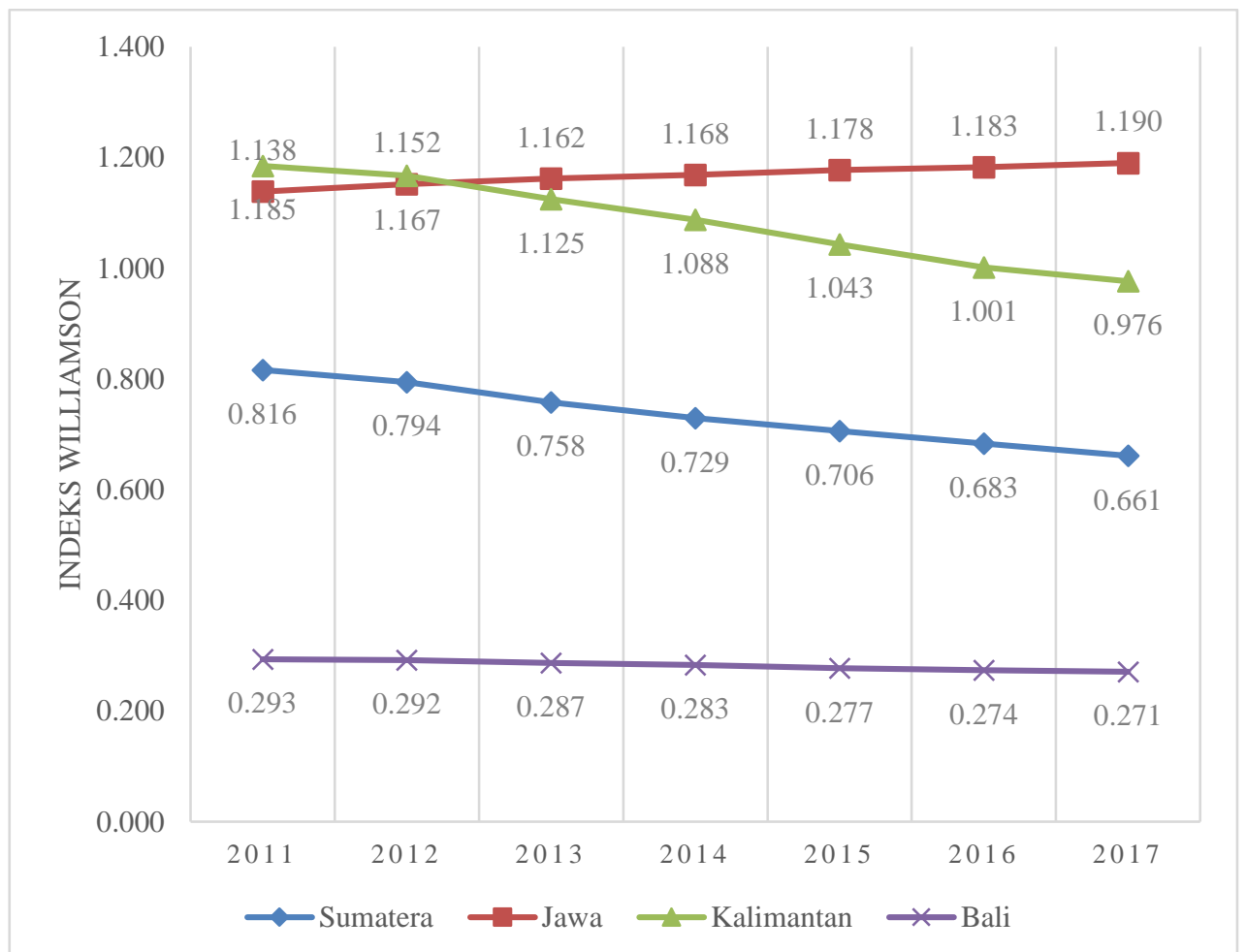

Gambar 3. Indeks Williamson Kawasan Barat Indonesia tahun 2011-2017

Untuk mengatasi masalah ketimpangan suatu daerah, pemerintah dapat melakukan perencanaan dengan menggunakan model konvergensi. Dengan menggunakan model konvergensi, diharapkan pemerintah dapat melakukan perencanaan dengan efektif. Selain itu, pemerintah juga dapat mengetahui berapa lama daerah mereka dapat mengejar daerah yang memiliki perekonomian yang lebih maju. Mankiw (2012) menjelaskan bahwa konvergensi merupakan alat ukur yang dapat digunakan untuk melihat tren laju pertumbuhan ekonomi dan ketimpangan pendapatan yang terjadi antarwilayah. Konvergensi terjadi ketika kabupaten/kota maju mengalami steady state, yaitu kondisi dimana tingkat pendapatan tidak dapat meningkat lagi dan kabupaten/kota yang relatif tertinggal mengalami peningkatan yang tinggi.

Namun, model yang menggambarkan konvergenitas sering mengabaikan kemungkinan adanya pola atau keterkaitan antar ruang (wilayah), sehingga model kurang mampu menggambarkan kondisi spasial (Arbia, 2006). Anselin (1998) berpendapat bahwa pengabaian adanya kemungkinan interaksi spasial diantara unit ekonomi dalam model dapat menyebabkan penarikan kesimpulan yang salah.

Penelitian mengenai konvergensi sudah banyak dilakukan, salah satunya dilakukan oleh Barro dan Martin pada tahun 1992. Barro dan Martin menggunakan data PDB per kapita pada tahun 1963 hingga 1986 di negara bagian Amerika Serikat. Di Indonesia, penelitian mengenai konvergensi dilakukan oleh Masrukhin (2009) dengan hasil bahwa PAD, pengeluaran pemerintah, persentase penduduk tamat SMA berpengaruh positif terhadap konvergensi di Jawa Barat. Selain itu, Fashollatain (2014) juga melakukan penelitian mengenai konvergensi dengan hasil bahwa terjadi konvergensi di Indonesia. Purwaningrum (2017) melakukan penelitian mengenai konvergensi di Jawa Tengah dengan hasil bahwa jumlah tenaga kerja, persentase panjang jalan baik terhadap panjang jalan kabupaten dan rata-rata lama sekolah dapat mempercepat terjadinya konvergensi. Penelitian mengenai konvergensi yang mempertimbangkan keterkaitan antarwilayah dilakukan oleh Abidin (2018) dengan hasil terjadi konvergensi di provinsi Jawa Timur dan variabel PAD, dana perimbangan, angka harapan sekolah dan hubungan antarwilayah memiliki pengaruh terhadap terjadinya konvergensi. 
Makin lebarnya kesenjangan pendapatan kabupaten/kota di Pulau Jawa menunjukkan semakin besarnya ketimpangan di Pulau Jawa. Hal ini akan menyebabkan kabupaten/kota yang relatif tertinggal semakin tertinggal dengan kabupaten/kota yang relatif maju. Untuk mengatasi hal tersebut, dilakukan analisis konvergensi untuk mengetahui apakah terjadi konvergensi. Selanjutnya juga terdapat beberapa faktor yang dapat memengaruhi terjadinya konvergensi di suatu daerah. Selain itu, terdapat adanya kemungkinan pengaruh spasial berpengaruh terhadap besarnya pendapatan pada kabupaten/kota di Pulau Jawa.

Adapun tujuan dari penelitian ini adalah (i) mendapatkan gambaran mengenai PDRB per kapita kabupaten/kota di Pulau Jawa dan hubungannya dengan variabel independen, (ii) mengkaji pengaruh spasial terhadap PDRB per kapita kabupaten/kota di Pulau Jawa, (iii) mengidentifikasi faktor-faktor dan pengaruhnya terhadap PDRB per kapita kabupaten/kota Pulau Jawa, dan (iv) mengkaji efek konvergensi PDRB per kapita kabupaten/kota di Pulau Jawa. Variabel yang digunakan dalam penelitian ini adalah PDRB per kapita, PAD, IPM, persentase jalan kabupaten berkategori baik, dan persentase angkatan kerja yang bekerja.

\section{METODE}

Konvergensi merupakan proses suatu negara yang tertinggal dapat mengejar negara maju. Dasar teori konvergensi adalah teori pertumbuhan ekonomi Solow dimana pada jangka panjang suatu perekenomian akan menuju ke kondisi steady state. Khikmawan (2018) menjelaskan ketika negara maju sudah berada dalam kondisi steady state dimana peningkatan investasi tidak lagi meningkatkan pendapatan sehingga pertumbuhan ekonomi akan melambat sementara itu negara berkembang akan mendapatkan tambahan investasi yang akan mempercepat pendapatan dan pertumbuhan ekonomi sehingga pada suatu saat pendapatan negara berkembang akan bertemu dengan negara maju.

Selain itu, adanya diminishing return skala hasil modal per tenaga kerja pada model Solow berkaitan dengan teori konvergensi, yaitu tidak selamanya negara kaya mengalami pertumbuhan ekonomi yang lebih besar. Negara dengan nilai modal per tenaga kerja yang rendah akan cenderung mengalami pertumbuhan yang lebih cepat. Sebaliknya, negara dengan nilai modal per tenaga kerja yang tinggi akan mengalami perlambatan pertumbuhan ekonomi (Abidin, 2018).

Karagiannis (2007) melakukan modifikasi pada pendekatan model panel dinamis sehingga persamaan yang digunakan sebagai berikut :

$$
\ln y_{i t}=\beta_{1} \ln y_{i, t-1}+\ln X_{i t} \beta+u_{i t}
$$

Keterangan :

$y_{\text {it }} \quad$ : variabel dependen pada individu ke-i tahun ke-t

$\mathrm{y}_{\mathrm{i}, \mathrm{t}-1} \quad$ : variabel dependen pada individu ke-i tahun ke-(t-1)

$\beta_{1}:(1-a)$

$\beta \quad$ : slope

$\mathrm{X}_{\mathrm{it}} \quad$ : variabel independen pada individu ke-I tahun ke-t

$\mathrm{u}_{\text {it }} \quad:$ il+vit

Berdasarkan persamaan diatas, konvergensi akan terjadi apabila $\beta_{1}$ nilai positif, kurang dari satu, dan signifikan (Islam, 1995).

Penelitian ini menggunakan data time series dan cross section pada tahun 2013-2017 pada kabupaten/kota di Pulau Jawa. Penelitian ini menggunakan analisis data panel dinamis dengan variabel dependen adalah PDRB per kapita dan variabel independen adalah PAD, IPM, persentase jalan kabupaten kategori baik, dan persentase angkatan kerja yang bekerja. Ditambah juga variabel keterkaitan antardaerah untuk melihat pengaruh suatu daerah mempengaruhi PDRB per kapita daerah lainnya dengan model yang akan digunakan adalah sebagai berikut :

$\ln {\text { PDR } \widehat{\text { Bkap }} \iota a_{\imath t}=\beta_{1} \ln \text { PDRBkapita }}_{i, t-1}+\beta_{2} \ln P A D_{i, t}+\beta_{3} \ln I_{P M_{i, t}}+\beta_{4} \ln$ jalan $_{i, t}+$

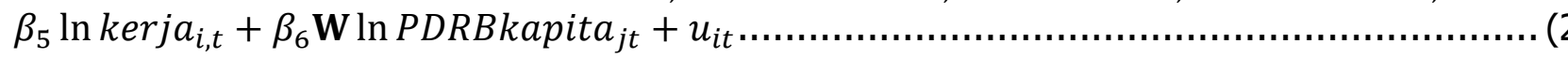




\section{HASIL DAN PEMBAHASAN}

Berdasarkan nilai PDRB per kapita, PDRB per kapita Pulau Jawa cukup tinggi dan selalu mengalami peningkatan tiap tahunnya. Pada tahun 2013, nilai PDRB per kapita Pulau Jawa sebesar 33,418 juta rupiah. Pada tahun 2014, PDRB per kapita Pulau Jawa mengalami peningkatan menjadi 34,883 juta rupiah. Lalu pada tahun 2015, PDRB per kapita Pulau Jawa naik menjadi 36,412 juta rupiah. Pada tahun 2016, PDRB per kapita Pulau Jawa meningkat menjadi 38,073 juta rupiah dan pada tahun 2017 PDRB per kapita Pulau Jawa meningkat menjadi 39,798 juta rupiah. Hal ini ditunjukkan pada Gambar 4.

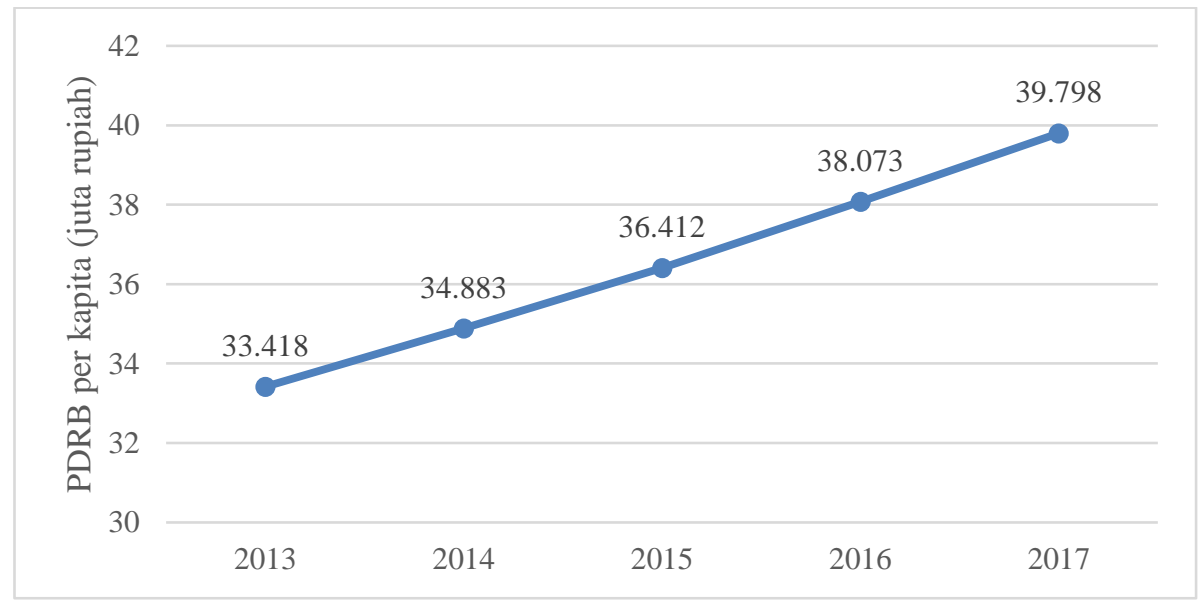

Sumber : Badan Pusat Statistik (diolah)

Gambar 4. PDRB per kapita Pulau Jawa Tahun 2013-2017.

Pada tahun 2013 berdasarkan Gambar 5(i), pendapatan per kapita kabupaten/kota di Pulau Jawa masih didominasi pendapatan rendah dan pendapatan menengah ke bawah. Hanya beberapa daerah yang memiliki pendapatan per kapita menengah ke atas dan tinggi. Kabupaten/kota yang memiliki pendapatan per kapita tinggi adalah Jakarta Pusat dan Kota Kediri. Selain itu, terdapat juga beberapa daerah yang memiliki pendapatan per kapita menengah ke atas, yaitu Kabupaten Bekasi, Kudus, Kota Semarang, Gresik, Surabaya serta kabupaten/kota di Provinsi DKI Jakarta selain Jakarta Pusat.

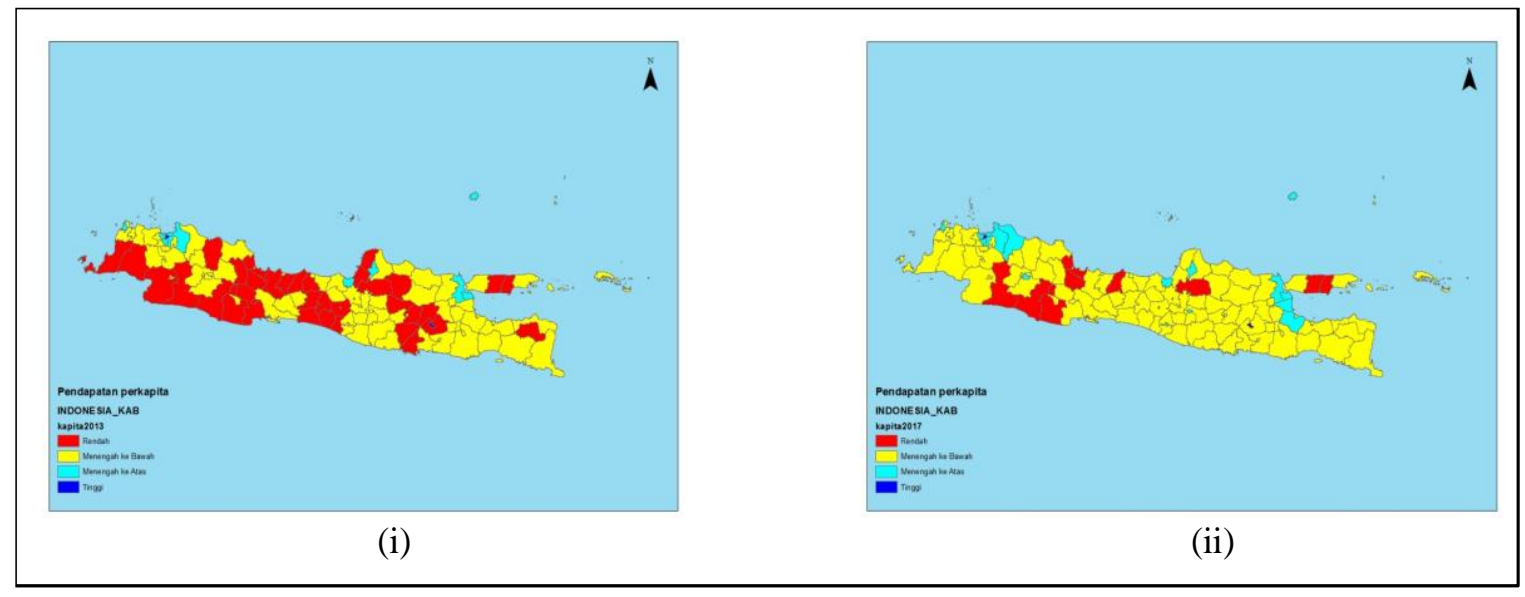

Sumber : Badan Pusat Statistik (diolah)

Gambar 5. PDRB per kapita kabupaten/kota di Pulau Jawa Tahun (i) 2013 dan (ii) 2017.

Lalu pada tahun 2017, terjadi perubahan pendapatan per kapita dimana kabupaten/kota di Pulau Jawa sudah mengalami peningkatan hingga pendapatan per kapita di Pulau Jawa didominasi oleh pendapatan menengah ke bawah. Beberapa daerah yang mengalami peningkatan dari pendapatan per kapita rendah menjadi pendapatan per kapita menengah ke bawah adalah Ciamis, Pandeglang, Lebak serta Subang. Hal ini menunjukkan adanya kemungkinan konvergensi terjadi di Pulau Jawa yang ditunjukkan dengan naiknya pendapatan per kapita kabupaten/kota di Pulau Jawa. 
Selain itu, terdapat juga kemungkinan adanya keterkaitan antardaerah di kabupaten/kota di Pulau Jawa. Hal ini ditandai dengan PDRB per kapita suatu daerah yang tinggi maka daerah sekitarnya juga tinggi atau menengah ke atas. Hal yang sama juga terjadi pada daerah yang memiliki PDRB per kapita menengah ke bawah dimana daerah di sekitarnya juga termasuk ke kategori menengah ke bawah atau rendah.

Pada variabel PAD, rata-rata PAD pada kabupaten/kota di Pulau Jawa mengalami peningkatan. Pada tahun 2013, rata-rata PAD kabupaten/kota di Pulau Jawa sebesar 268 miliar rupiah lalu pada tahun 2014 naik menjadi 373 miliar rupiah. Pada tahun 2015, rata-rata PAD kabupaten/kota di Pulau Jawa naik menjadi 433 miliar rupiah. Lalu pada tahun 2016, rata-rata PAD kabupaten/kota Pulau Jawa naik menjadi 471 miliar rupiah dan pada tahun 2017 naik menjadi 496 miliar rupiah. Hal ini ditunjukkan pada Gambar 6.

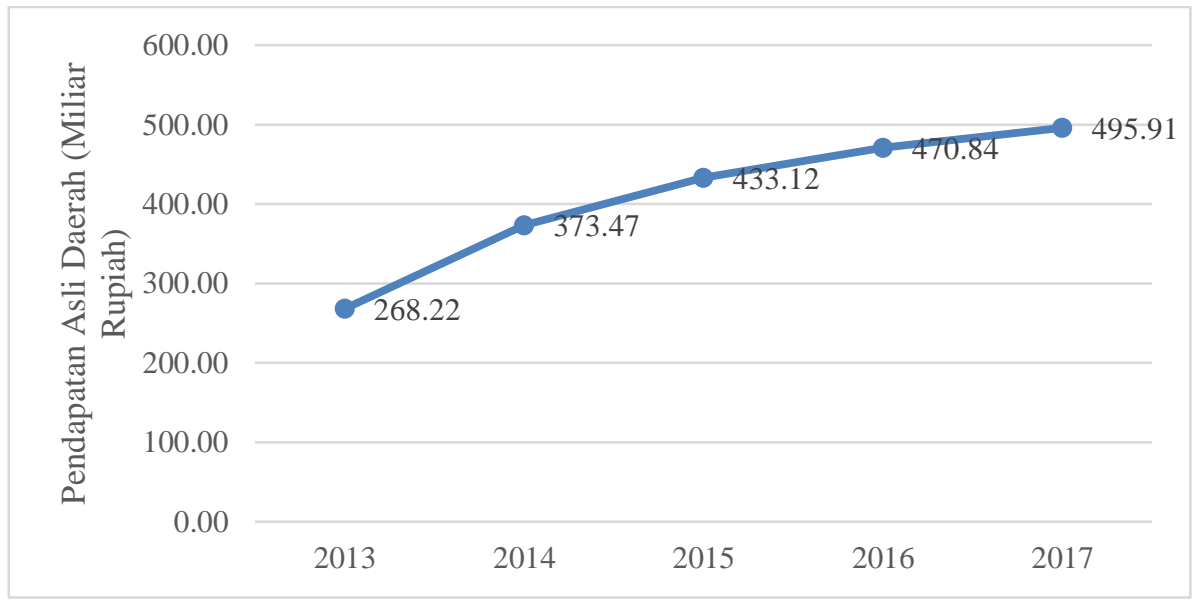

Sumber : Badan Pusat Statistik (diolah))

Gambar 6. Rata-rata PAD Pulau Jawa Tahun 2013-2017

Pada variabel IPM, berdasarkan data dari tahun 2013 hingga 2017, rata-rata IPM kabupaten/kota di Pulau Jawa mengalami peningkatan. Pada tahun 2013, rata-rata IPM kabupaten di Pulau Jawa sebesar 69,11. Pada tahun 2014, rata-rata IPM kabupaten/kota di Pulau Jawa meningkat menjadi 69,57. Selanjutnya pada tahun 2015, rata-rata IPM kabupaten/kota di Pulau Jawa meningkat menjadi 70,27. Pada tahun 2016, rata-rata IPM pada kabupaten/kota di Pulau Jawa meningkat menjadi 70,85 dan pada tahun 2017 menjadi 71,41. Adanya peningkatan IPM pada kabupaten/kota di Pulau Jawa menunjukkan adanya perubahan positif pada dimensi-dimensi dasar yang digunakan dalam menyusun IPM, yaitu pengetahuan, umur panjang dan hidup sehat, dan standar hidup layak.

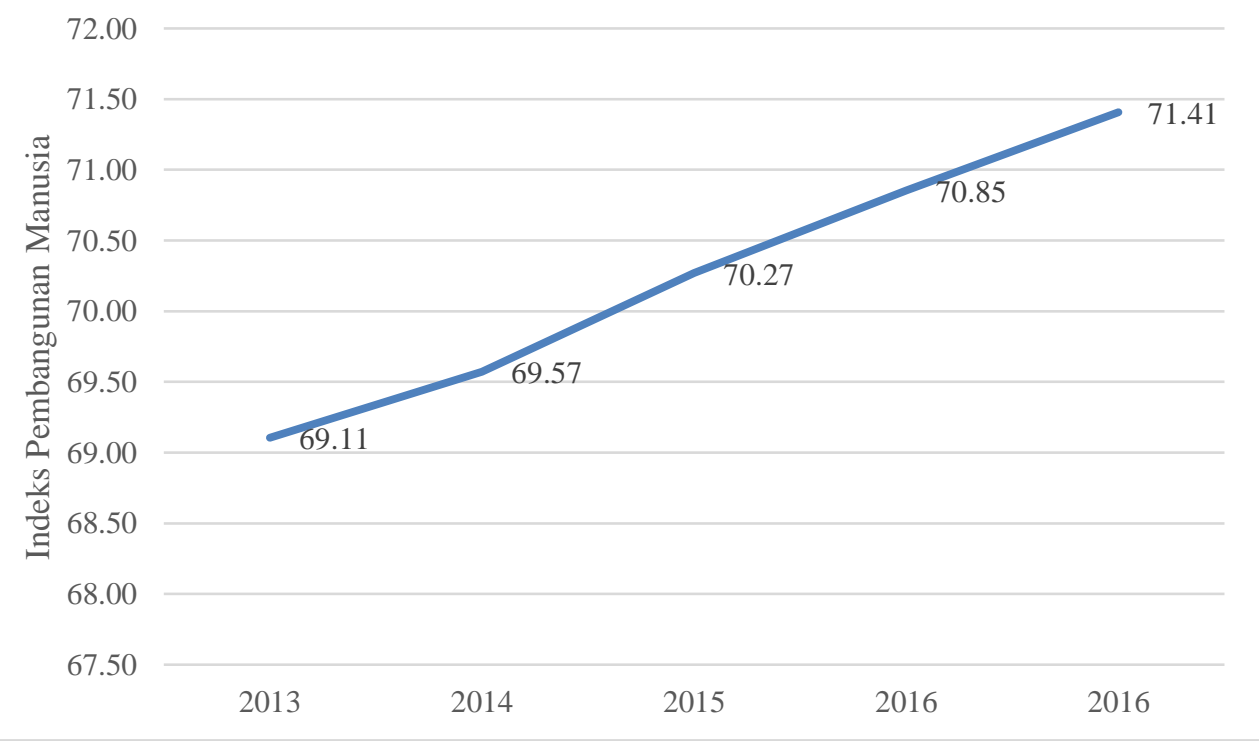

Sumber : Badan Pusat Statistik (diolah)

Gambar 7. Rata-rata IPM kabupaten/kota Pulau Jawa Tahun 2013-2017 
Untuk variabel persentase jalan kabupaten berkategori baik pada tahun 2013 hingga tahun 2017, pesentase jalan kabupaten yang berkategori baik selalu meningkat. Pada tahun 2013, persentase jalan kabupaten yang berkategori baik sebesar 53,16\%. Pada tahun 2014, persentase jalan kabupaten yang berkategori baik meningkat menjadi 55,14\% dan pada tahun 2015 kembali meningkat menjadi 55,36\%. Lalu pada tahun 2016, persentase jalan kabupaten yang masuk ke dalam kategori baik meningkat menjadi 55,95\% dan pada tahun 2017 kembali meningkat menjadi $56,80 \%$. Hal ini ditunjukkan oleh Gambar 8.

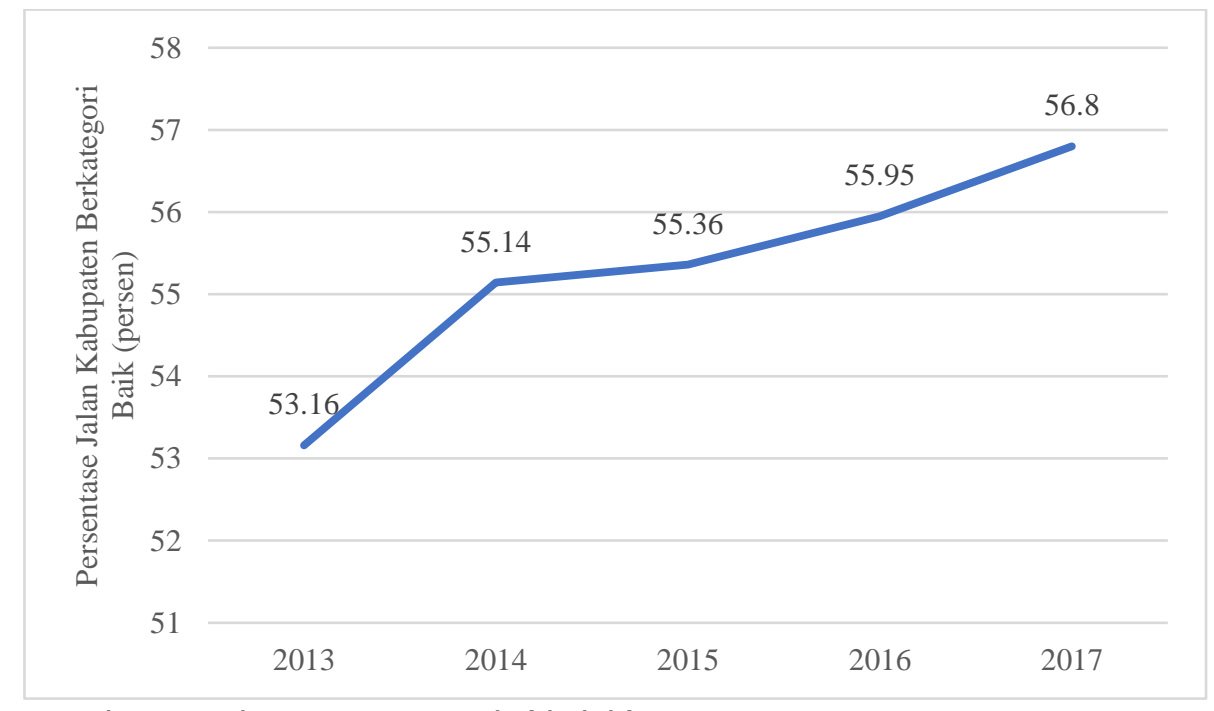

Sumber : Badan Pusat Statistik (diolah)

Gambar 8. Persentase Jalan berkategori baik tahun 2013-2017

Lalu untuk variabel persentase angkatan kerja yang bekerja pada tahun 2013 hingga tahun 2017, pesentase angkatan kerja yang bekerja pada kabupaten/kota di Pulau Jawa selalu meningkat. Pada tahun 2013, persentase angkatan kerja yang bekerja sebesar 93,19 persen. Pada tahun 2014, persentase angakatan kerja yang bekerja meningkat menjadi 93,54 persen. Pada tahun 2015 persentase angkatan kerja yang bekerja meningkat menjadi 93,59 persen. Lalu pada tahun 2016, persentase angkatan kerja yang bekerja kembali meningkat menjadi 93,84 persen dan pada tahun 2017 kembali meningkat menjadi 94 persen.

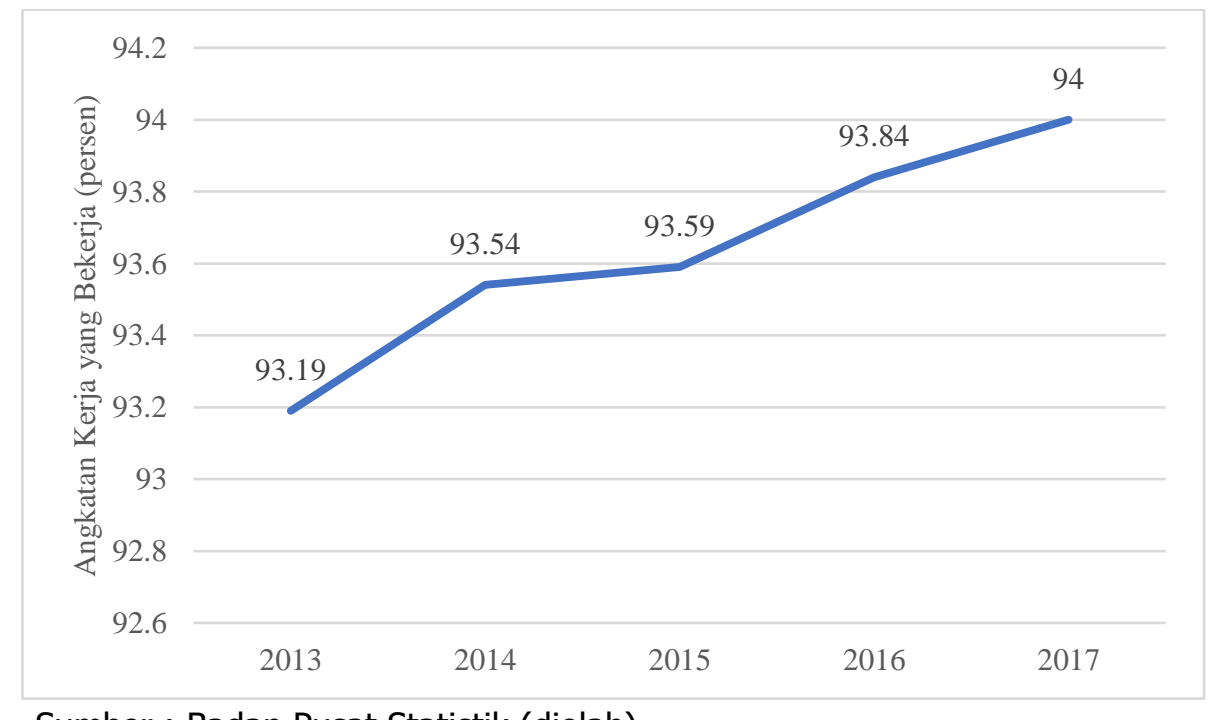

Sumber : Badan Pusat Statistik (diolah)

Gambar 9. Persentase Angkatan Kerja yang Bekerja

Konvergensi beta kondisional spasial merupakan analisis konvergensi beta kondisional dengan mempertimbangkan keterkaitan antardaerah. Sebelum membetuk model pada konvergensi beta 
kondisional spasial, dilakukan uji Moran's I untuk mengetahui apakah terdapat hubungan spasial antar kabupaten/kota di Pulau Jawa

Tabel 1. Hasil Uji Moran's I.

\begin{tabular}{cc} 
Moran's I & $p$-value \\
\hline 0,176 & $0,003472^{*}$ \\
\hline
\end{tabular}

Ket. : * signifikan pada tingkat signifikansi 5 persen

Berdasarkan pada Tabel 1, diketahui bahwa terdapat keterkaitan antar kabupaten/kota di Pulau Jawa pada tahun 2013-2017, sehingga dapat dilakukan pemodelan untuk konvergensi beta kondisional spasial.

Tabel 2. Konvergensi Beta Kondisional Spasial Kabupaten/Kota Pulau Jawa.

\begin{tabular}{|c|c|c|c|}
\hline Parameter & Koefisien & Standar error & $p$-value \\
\hline Ln pdrbkapita-1 & 0,875 & 0,171 & $0,000 *$ \\
\hline Ln PAD & 0,004 & 0,002 & $0,022 *$ \\
\hline Ln IPM & 0,163 & 0,000 & $0,007 *$ \\
\hline Ln Jalan & 0,001 & 0,061 & $0,022 *$ \\
\hline Ln Kerja & 0,019 & 0,006 & $0,003 *$ \\
\hline wlnpdrbkap & 0,093 & 0,021 & $0,000 *$ \\
\hline Speed & & & \\
\hline Convergence $(\lambda)$ & & & 13,31 \\
\hline Half & & & \\
\hline convergence & & & 5,206 \\
\hline Arrelano & & & \\
\hline (m1) & & 0,054 & 0,008 \\
\hline $\begin{array}{l}\text { Arrelano Bond } \\
(\mathrm{m} 2)\end{array}$ & & 0,968 & 0,325 \\
\hline Sargan & & 22,575 & 0,2074 \\
\hline Speed & & & \\
\hline Convergence $(\lambda)$ & & & 13,31 \\
\hline Half & & & \\
\hline convergence & & & 5,206 \\
\hline
\end{tabular}

Ket. : * signifikan pada tingkat signifikansi 5 persen

Berdasarkan tabel 2, didapatkan model yang terbentuk sebagai berikut :

$\ln$ PDR $\widehat{\text { Bkap }} \iota a_{l, t}=0,875 \ln P D R B k a p i t a_{i, t-1}^{*}+0,004 \ln P A D_{i t}^{*}+0,163 \ln I P M_{i t}^{*}+0,001 \ln$ Jalan $_{i t}^{*}+$ 0,019 $\ln$ Kerja $_{i t}^{*}+0,093 \mathbf{W}$ lnpdrbkapita $a_{t}^{*}$

Selanjutnya, pada uji arrelano bond, didapatkan hasil bahwa parameter sudah konsisten karena pada $\mathrm{m} 1$ tolak $\mathrm{HO}$ dan pada $\mathrm{m} 2$ gagal tolak $\mathrm{H} 0$ dengan tingkat signifikansi 5 persen. Lalu, pada asumsi validitas instrumen yang dilihat dari uji Sargan, diketahui hasil yang didapatkan adalah tolak $\mathrm{HO}$ pada tingkat signifikansi 5 persen sehingga instrumen sudah valid.

Berdasarkan nilai koefisien pada PDRB per kapita tahun sebelumnya, diketahui terjadi konvergensi beta kondisional spasial di pulau Jawa. Ini menandakan bahwa daerah yang tertinggal dapat mengejar daerah yang sudah maju sehingga proses konvergensi dapat terjadi. Dengan adanya variabel keterkaitan antardaerah, proses terjadinya konvergensi lebih cepat. Selanjutnya, dari keempat variabel yang digunakan, semuanya memiliki pengaruh secara signifikan terhadap pendapatan per kapita suatu daerah.

Pada model beta kondisional spasial, diketahui bahwa kecepatan konvergensi yang terjadi setiap tahunnya adalah sebesar 13,31 yang berarti bahwa pertumbuhan ekonomi pada daerah tertinggal 13,31 persen lebih besar daripada pertumbuhan ekonomi di daerah maju dan dibutuhkan waktu 5,206 tahun untuk menutup setengah kesenjangan awal pada daerah tertinggal dengan daerah maju.

Variabel PDRB per kapita memiliki hubungan positif dan signifikan pada tingkat signifikansi sebesar 5 persen. Pada PDRB per kapita, setiap kenaikkan 1 persen periode saat ini akan meningkatkan PDRB per kapita periode selanjutnya sebesar 0,875 persen. 
Variabel PAD memiliki pengaruh positif dan signifikan pada tingkat signifikansi sebesar 5 persen. Hal ini menandakan bahwa setiap kenaikkan 1 persen PAD akan meningkatkan PDRB per kapita sebesar 0,004 persen. Hal ini menandakan bahwa adanya peran PAD dalam mempercepat proses konvergensi ekonomi pada kabupaten/kota dimana PAD sebagai sumber dana pemerintah digunakan untuk melaksanakan program kerja demi menciptakan kesejahteraan rakyat (Septian, 2016). Setyawati dan Ardi (2007) menjelaskan bahwa kenaikkan PAD dapat mengoptimalkan dan meningkatkan aktivitas pada sektor-sektor ekonomi sehingga dapat disimpulkan bahwa PAD memiliki hubungan yang positif terhadap pertumbuhan ekonomi dan secara tidak langsung juga terhadap pendapatan.

Variabel IPM memiliki pengaruh positif dan signifikan pada tingkat signifikansi sebesar 5 persen. Hal ini dapat diartikan, setiap kenaikkan 1 persen IPM akan meningkatkan PDRB per kapita sebesar 0,163 persen. Hal ini menandakan bahwa IPM yang tinggi dapat menggambarkan bahwa kualitas sumber daya manusia yang dimiliki oleh suatu daerah yang baik. Dengan kualitas sumber daya manusia yang baik, suatu daerah dapat memproduksi barang lebih banyak dan memiliki kualitas yang lebih tinggi sehingga mendapatkan pendapatan yang lebih tinggi.

Variabel persentase jalan kabupaten yang berkategori baik memiliki pengaruh positif dan signifikan pada tingkat signifikansi sebesar 5 persen. Hal ini menandakan setiap kenaikkan persentase jalan sebesar 1 persen akan meningkatkan PDRB per kapita sebesar 0,001 persen. Hal ini menandakan bahwa dengan kualitas jalan yang baik, mobilisasi barang dari satu daerah ke daerah lain juga menjadi lebih mudah. Ketersediaan infrastruktur jalan yang memadai akan menjadikan distribusi barang dan jasa menjadi lebih cepat dan efisien dalam hal biaya dan waktu, sehingga memudahkan para investor dalam berusaha. Semakin panjang dan baik kualitas jalan, maka akan memperlancar distribusi barang dan jasa yang pada akhirnya akan menarik investasi dan meningkatkan kegiatan perekonomian, serta meningkatkan pendaptan per kapita. (Adi dalam Nurhamidah (2014)).

Pada variabel persentase angkatan kerja yang bekerja memiliki pengaruh positif dan signifikan pada tingkat signifikansi sebesar 5 persen. Hal ini dapat diartikan bahwa setiap kenaikkan persentase angkatan kerja yang bekerja sebesar 1 persen akan menaikkan PDRB per kapita sebesar 0,019 persen. Hal ini menandakan bahwa pertumbuhan tenaga kerja secara tradisional dianggap sebagai salah satu faktor positif yang memacu pertumbuhan ekonomi karena jumlah tenaga kerja yang besar akan menambah jumlah tenaga kerja yang produktif (Saragih, 2016). Pengaruh tenaga kerja terhadap pertumbuhan ekonomi sepenuhnya tergantung pada kemampuan sistem perekonomian daerah yang bersangkutan untuk menyerap dan memanfaatkan secara produktif tenaga kerja di daerah yang bersangkutan (Todaro, 2003). Apabila persentase tenaga kerja meningkat maka hal ini akan mendorong peningkatan output regional dengan asumsi peningkatan rasio tenaga kerja diikuti pula dengan peningkatan produktivitas.

Pada efek keterkaitan antardaerah memiliki pengaruh positif dan signifikan pada tingkat signifikansi sebesar 5 persen sejalan dengan penelitian Abidin (2018). Hal ini dapat diartikan bahwa setiap kenaikkan satu persen PDRB per kapita pada suatu daerah akan menaikkan PDRB per kapita daerah lain sebesar 0,093 persen dimana 0,093 persen tersebut akan terbagi menurut seberapa banyak suatu daerah berhubungan dengan daerah lainnya.

\section{KESIMPULAN}

Berdasarkan hasil dan pembahasan yang telah dibahas sebelumya, didapatkan kesimpulan (i) PDRB per kapita di kabupaten/kota di Pulau Jawa mengalami kenaikkan setiap tahunnya, (ii) terdapat pengaruh spasial pada PDRB per kapita kabupaten/kota di Pulau Jawa, (iii) variabel PAD, IPM, persentase jalan kabupaten berkategori baik, dan persentase angkatan kerja yang bekerja berpengaruh positif, dan signifikan sehingga berpengaruh terhadap terjadinya konvergensi, dan (iv) terjadi konvergensi beta kondisional spasial dimana dibutuhkan waktu selama 5,206 tahun untuk menutup setengah kesenjangan.

Saran yang diberikan peneliti terhadap pemerintah adalah (i) Meningkatkan kemampuan modal manusia dengan cara memberikan pelatihan kerja, penyuluhan kesehatan, melaksanakan program gratis sekolah 12 tahun dan apabila memungkinkan pemberian modal sehingga masyarakat dapat 
bersaing di dunia kerja, (ii) Melakukan promosi pada daerahnya, sebagai contoh pada sektor pariwisata dan juga pada sektor industri sehingga pendapatan daerah akan meningkat, (iii) Melakukan perbaikkan serta penambahan jalan yang belum berkategori baik. Hal ini dikarenakan jalan merupakan salah satu sarana yang digunakan pengusaha untuk mendistribusikan produknya. Sehingga dengan baiknya kondisi jalan akan memudahkan distribusi barang tersebut, (iv) Bagi pemerintah daerah dapat membuat perjanjian dengan daerah disekitarnya dalam rangka pembangunan ekonomi, dan (v) Untuk penelitian selanjutnya dapat menggunakan jarak ekonomi sebagai penimbang spasial.

\section{UCAPAN TERIMA KASIH}

Kami ucapkan terima kasih kepada Bapak Odry Syafwil, M.Si dan Ibu Dr. Ernawati Pasaribu, S.Si., M.E. yang telah membantu dalam mengkoreksi penelitian ini. Kami juga ucapkan terima kasih kepada Badan Pusat Statistik yang telah menyediakan data dan informasi yang mendukung terlaksananya penelitian ini.

\section{DAFTAR PUSTAKA}

Abidin, A.B. (2018). Analisis Konvergensi Pendapatan Provinsi Jawa Timur Tahun 2010-2016 :Pendekatan Model Panel Dinamis Spasial. Skripsi Sekolah Tinggi Ilmu Statistik, Jakarta.

Anselin, L. (1988). Spatial Econometrics: Methods and Models. Kluwer Academic Publishers.

Arbia, G. (2006). Spatial Econometrics: Statistical Foundation Application to. Regional Convergence. Springer. Baltagi, B.H. (2005). Econometric Analysis of Panel Data 3rd Edition. John Wiley \& Sons.

Barro, Robert J dan Xavier Sala-i-Martin. (1992). Convergence. Journal of Political Economy 100(2):223-251

Fashollatain, A. (2014). Analisis $\sigma$ dan $\beta$ Convergence Pertumbuhan Ekonomi Indonesia Tahun 2002-2012. Skripsi Universitas Diponegoro, Semarang.

Gujarati, D.N. (2003). Basic Econometrics 4th Edition. McGraw-Hill.

Islam, N. (1995). Growth Empirics: A Panel Data Approach. The Quarterly of Economics, 110(4).

Karagiannis, S. (2007). The Knowledge-Based Economy, Convergence and Economic Growth: Evidence from the European Union. Greece: Centre of Planning and Economic Research 11, Amerikis Street, 10672 Athens.

Khikmawan, M.R. (2018). Analisis Konvergensi PDRB per Kapita Kabupaten/Kota di Provinsi Banten Tahun 2010-2015. Skripsi Sekolah Tinggi Ilmu Statistik, Jakarta.

Mankiw, N. G. (2012). Macroeconomics 8th Edition. Worth Publishers.

Masrukhin.(2009). Konvergensi Pendapatan Antar Kabupaten/kota di Provinsi Jawa Barat Periode 2000-2007. Skripsi Institut Pertanian Bogor, Bogor.

Nurhamidah, R. (2014). Determinan Konvergensi Pendapatan di Provinsi Sumatera Selatan. Skripsi Sekolah Tinggi Ilmu Statistik, Jakarta.

Nurhuda, R., M.R Khairul Muluk, dan Wima Yudi Prasetyo. (2011). Analisis Ketimpangan (Studi di Provinsi Jawa Timur 2005-2011). Jurnal Administrasi Publik, 1(4), 110-119.

Purwandari, A.E. (2016). Pendekatan Model Panel Dinamis dalam Kajian Konvergensi Pendapatan Provinsi Daerah Istimewa Yogyakarta Tahun 2003-2014. Skripsi Sekolah Tinggi Ilmu Statistik, Jakarta.

Purwaningrum, A.P. (2017). Analisis Konvergensi Kabupaten/Kota di Provinsi Jawa Tengah Tahun 2010-2015. Skripsi Sekolah Tinggi Ilmu Statistik, Jakarta.

Rahayu, N.R. (2017). Ketimpangan Pembangunan dan Faktor-Faktor yang Memengaruhi Pertumbuhan Ekonomi Provinsi di Indonesia 2010-2016. Skripsi Sekolah Tinggi Ilmu Statistik, Jakarta

Saputra, S.N. (2015). Ketimpangan dan Konvergensi Pendapatan Antarkabupaten/kota di Provinsi Lampung Tahun 2009-2013. Skripsi Sekolah Tinggi Ilmu Statistik, Jakarta.

Saragih, P. (2016). Analisis Konvergensi PDRB per Kapita Antar Provinsi di Pulau Sumatera Tahun 2005-2014. Skripsi Sekolah Tinggi Ilmu Statistik, Jakarta.

Septian, M. (2016). Analisis Kecenderungan Konvergensi Ekonomi Daerah Tertinggal dan Daerah Maju (Studi Kasus Kabupaten/Kota di Provinsi Sumatera Utara 2010-2014). Skripsi Sekolah Tinggi Ilmu Statistik, Jakarta.

Septika, I. (2016). Konvergensi Ekonomi Antarkabupaten/kota di Provinsi Papua Barat Periode 2010-2014. Skrpsi Sekolah Tinggi Ilmu Statistik, Jakarta

Setyawati, A., Ardi Hamzah. (2007). Analisis Penaruh PAD, DAU, DAK dan Belanja Pembangunan Terhadap Pertumbuhan Ekonomi.Kemiskinan dan Pengangguran: Pendekaan Jalur Analisis. Jurnal Akutansi dan Keuangan Indonesia, 4(2), 211-228.

Sjafrizal. (2017). Ekonomi Wilayah dan Perkotaan. Raja Grafindo Persada.

Todaro, M.P \& Smith, S.C. (2003). Pembangunan Ekonomi di Dunia Ketiga Edisi. Ke-8. Vol.2.Erlangga. 
Verbeek, M. (2004). A Guide to Modern Econometrics 2nd Edition. John Wiley and Sons.

Wahyuni, K. (2011). Konvergensi dan Faktor-faktor yang Memengaruhi Ketimpangan Wilayah Kabupaten/Kota Di Pulau Jawa. Tesis Institut Pertanian Bogor, Bogor. 